\title{
THE INFLUENCE OF THE VARIATION OF TEXTURING PROCESS PARAMETERS ON STRUCTURAL CHARACTERISTICS OF POLYAMIDE TEXTURED YARNS IN THE FALSE TWIST
}

Marija Savić1 ${ }^{\star}$, Dusan Trajković ${ }^{1}$, Petar Stojanović$^{2}$, Jovan Stepanović ${ }^{1}$

(ORIGINAL SCIENTIFIC PAPER)

UDC 677.072.7:677.022

${ }^{1}$ Faculty of Technology, Leskovac, Serbia

2Dunav a.d. Grocka, Serbia

The variation of texturing process parameters within the limits of the industrial texturing machine brings about substantial structural changes of yarn characteristics. To obtain required characteristics of textured PA6.6 yarns for specific purposes, it is necessary to adjust the optimum process parameters. For that reason, in addition to modification of the quality of textured polyamide yarns, the aim of this work is to define the limit values of the texturing process. In this work, the influence of technical-technological parameters in the false twist texturing process on structural characteristics of polyamide yarns was studied. Partially oriented POY multifilament of $22 \mathrm{f0} 7 \times 1 \mathrm{dtex}$ fineness was textured under production conditions on the friction texturing machine ICBT, model FT 15 E3. Using low temperature long heaters, the influence of variations of the heater temperature, texturing speed and $D / Y$ ratio on the properties of the textured yarn (filament density, the crystallinity degree, the orientation degree of individual filaments, end $-\mathrm{NH}_{2}$ group content, $-\mathrm{COOH}$ group content and the total content of end groups) was investigated. Thereby, the values for the tension in the texturing zone (stretching) of 1.305 and in the winding zone of 0.954 were kept constant. The studied texturing parameters affect the change of above mentioned characteristics to a varying degree. For heater temperatures of 200,210 and $220^{\circ} \mathrm{C}$, and $\mathrm{D} / \mathrm{Y}$ ratio of $1.7,1.9,2.1$ and 2.3 , negative linear correlations were found between the speed of texturing - filament density, the speed of texturing - the degree of crystallinity and the speed of texturing - the degree of orientation of individual filaments. The correlation factor between the texturing process parameters and the analyzed properties of the yarn was determined. Based on the analysis of the obtained results, it can be concluded that with the established correlation between the speed of texturing and the investigated properties of the yarn, the correlation factor generally increases with the increase of $D / Y$ ratio to 1.9 and 2.1 , for the heater temperature up to $210^{\circ} \mathrm{C}$. However, in most cases the correlation factor decreases at the temperatures above $220^{\circ} \mathrm{C}$ and higher values of the $\mathrm{D} / \mathrm{Y}$ ratio. Therefore, in this study, the optimum temperature of the heater is $210^{\circ} \mathrm{C}$ and $\mathrm{D} / \mathrm{Y}$ ratio from 1.9 to 2.1 , taking into account the selection of other values of texturing speed parameters and stretching.
Keywords: false twisting, texturing parameters, textured yarn, structural characteristics

\section{Introduction}

In the production process of a synthetic fiber there is a mutual relationship between technological parameters of the production, the formation of supra-molecular and microstructure of the fiber and properties of produced fibers. This means that, by varying the technological parameters of the production, the structure of the fibers can be influenced and thus their properties [1-3]. During the process of texturing, under the influence of mechanical forces and heat a disorientation of structural elements at all levels of supra-molecular structures occurs. At the same time, micro-cavities are formed increasing disorientation and the amount of micro-cavities in the cross section of elementary threads. This increases the sorption capacity of the yarn.

The temperature of the heater, as one of the important process parameters, and its influence on the properties of textured yarns were the subject of many previous studies [4-6]. During texturing, structural changes occur,

\footnotetext{
*Author address: Marija Savić, Faculty of Technology, University of Niš, Bulevar oslobodjenja 124, 16000 Leskovac, Serbia

E-mails: marisavi82@yahoo.com

The manuscript received: September, 27, 2016.

Paper accepted: October, 11, 2016.
} 
primarily disorientation of macromolecular chains. On one hand, any torsion stress helps the disorientation of molecular chains. On the other hand, the tension load leads to further orientation of crystalline and amorphous parts of molecular chains. The textured yarn crystallinity degree increases and the yarn strength and tightening modulus decrease as a result of the decline of the degree of crystal orientation with increasing the heater temperature. The orientation of molecules has a greater influence on mechanical properties of the yarn than the increase of the crystal area portion.

For most of the existing texturing systems the $\mathrm{D} / \mathrm{Y}$ ratio (ratio of circumferential or "surface" speed of the disc to a linear speed of yarn) has a value of 1.4 to 3.0. The values of $D / Y$ ratio of the tension regulate the tension ratio $T_{2} / T_{1}[7]$, where $T_{1}$ is the yarn tension before and $T_{2}$ the yarn tension after the friction unit. When setting, the $\mathrm{D} / \mathrm{Y}$ ratio has the aim to balance the tension and stabilize the yarn on both sides of the friction unit, the tension ratio is $T_{2} / T_{1}=1.0$. If the output tension $T_{2}$ is lower than the input tension $T_{1}, \frac{T_{2}}{\tau_{1}}>1$, then which is caused by a high $\mathrm{D} / \mathrm{Y}$ ratio, i.e. tou rast rotation of the friction discs. This is an unstable situation and when the tension ratio falls below 0.8 , the irregularities of the yarn twist occur. If the output tension $\mathrm{T}_{2}$ is higher than the input tension $T_{1}, \frac{T_{2}}{T_{1}}>1$, friction discs rotate too slowly, i.e. $\mathrm{D} / \mathrm{Y}$ ratio is too iuw. in this case the yarn is practically pulled through the friction unit. This is a very stable situation in the friction unit, but it leads to the mechanical yarn damage, i.e. breaking filaments in the multifilament, but in the case of polyurethane discs the disc wear is increased.

$D / Y$ ratio is calculated as follows, [7] (equation 1):

$\mathrm{D} / \mathrm{Y}$ ratio $=\frac{\text { disc diameter }(\mathrm{m}) \cdot \pi \cdot \text { disc revolutions per time unit }}{\text { flow speed }}$

By changing the texturing speed, the yarn contact time with the heater and yarn cooling time are changed too. The increase of the texturing speed brings about the voluminosity drop, increases breakability and tension in the yarn, increases the number of breaks of individual threads in the yarn, but when reducing the speed the above mentioned problems are reduced by enabling an easier process control.

Adjusting parameters of the texturing machine have great influence on the properties of textured yarns [8].

Fiber crystallinity and orientation degrees present important parameters of fiber supra-molecular structure. The ratio of participation of a certain characteristic of the crystal (or amorphous) regions to the same characteristic of both regions represents a crystallinity degree. It is related both to the production conditions and processing of the polymer and to the processing of polymer products. Some of the suitable test methods are: electron spectroscopy in polarized light, $x$-ray diffraction, infrared spectroscopy, methods for density measurement, etc.

Another important characteristic of the supra-molecular structure is molecular orientation in some direction which is expressed by the orientation degree. It can be considered as the orientation of crystal regions, the orientation of amorphous regions and the average orientation which represents the middle value of both. A molecular orientation in the crystal region can be expressed relative to the fiber axis, to some crystallographic direction (usually c axis), or some other external direction serving as an etalon. The orientation degree in the crystal region can be determined by X-ray diffraction while the method based on birefringence (double refraction) gives the average orientation for both regions. As a parameter of supra-molecular structure, the orientation degree has great influence on the breaking strength, breaking elongation [9] and other mechanical properties of linear polymers. When macromolecular orientation in fibers is lower, the fiber breaking elongation is higher and vice versa.

It is known from literature that filament density is reduced by texturing, probably due to the intensive formation of voids, and in some cases the crystallinity degree can be reduced too. However, some individual investigations of the change in a textured polyamide yarn with heater temperatures of $190-230^{\circ} \mathrm{C}$ show that the density increases with increasing the heater temperature [10]. Also, the increase in the heater temperature brings about the increase of the yarn orientation. It was found that during the texturing of polyamide filament, the degree of crystallinity increases relative to the beginning and even more so if the temperature of the heat treatment is higher. With increasing the time of the heat treatment at higher temperatures, there is the increase in the crystal size compared to the non textured filament. The change of crystallinity in the texturing depends on the fineness of the filament and the type of crystallographic lattice in the starting filament [11].

Chemical properties of polyamide fibers are determined by their chemical composition and structure, primarily by the content of end groups. Surface energy of polyamide fibers depends on the content of $-\mathrm{NH}_{2}$ and $-\mathrm{COOH}$ groups and has a great significance in the processing and application of these fibers [12]. Surface energy plays an important role in the finishing process.

\section{Experimental}

Multifilament yarn POY PA6.6 fineness $22 \mathrm{f} 07 \times 1$ was used as the experiment material. The samples were made in the production conditions on the texturing machine ICBT model FT 15 E3 (with a long heater) by changing technical-technological parameters as follows: temperatures in the heating zone were 200, 210 and 220 ${ }^{\circ} \mathrm{C}$, textured yarn exiting speeds were $600,700,800$ and $900 \mathrm{~m} / \mathrm{min}$, disc surface speed to yarn linear speed ratios $\mathrm{D} / \mathrm{Y}$ were 1.7, 1.9, 2.1, and 2.3. The values of the yarn tension in the texturing zone (stretching) of 1.305 and in the winding zone of 0.954 were kept constant. Discs configuration was 1-4-1 and they were ceramic with the $52 \mathrm{~mm}$ diameter and the thickness of $9 \mathrm{~mm}$.

The following test methods were used for testing the laboratory material: 
- The fiber crystallinity degree was determined by measuring a specific mass, based on the fact that crystal regions, due to molecular order and geometrically more regular arrangement, have denser packing and, therefore, higher density than amorphous regions. In that way, fibers with a higher crystallinity degree have higher density. In order to use this method, first it is necessary to know the density. By using calibration curves for PA6.6 fibers, the density is correlated with the crystallinity degree.

- For testing the density (specific mass), the apparatus for the determination of a specific mass was used. Prepared bundles of PA6.6 fibers were soaked with $20 \mathrm{ml}$ of benzene $\left(\mathrm{C}_{6} \mathrm{H}_{6}\right)$. After removing the air bubbles by pressing fibers on the vessel wall, carbon tetra chloride was slowly added until the fibers began to levitate in the mixture. At that moment, the density of the tested sample was equal to the density of the mixture.

- For the determination of the fiber orientation degree, the interferential method based on polarized microscopy and the measuring of double refraction of fibers was used. The results of the fiber orientation measurement are expressed through the values of double refraction (ne-no), where higher values mean better orientation of the fiber in axial direction. The measuring of the orientation degree was made by polarized light microscope MIN8 with five measurements per each sample, and the results are presented as mean value. To apply this method it was necessary to know the fiber diameter.

- The fiber diameter (d) was determined on microscope MIN8 by using a micrometer eyepiece with mag-

\section{(a) $D / Y 1.7$}

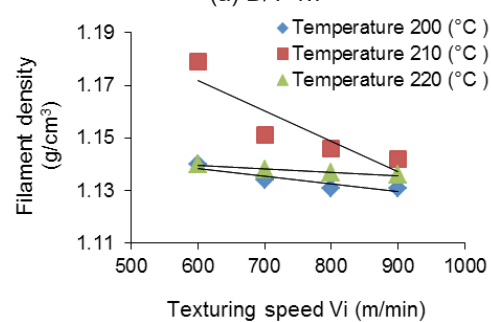

(c) $\mathrm{D} / \mathrm{Y} 2.1$



nification of $5 \mathrm{x}$ and the objective with the magnification of $40 x$.

- The content of end groups of polyamide textured yarns was determined by the end group titration method. The end groups were calculated on the basis of the solution volume in $\mathrm{ml}$ used for the titration of $1 \mathrm{~g}$ of polyamide. The content of end groups is expressed in $\mathrm{mmol} / \mathrm{g}$ of the fiber. The total content of end groups was calculated as a sum of amino and carboxyl group contents ( $\mathrm{mmol} / \mathrm{g}$ of fiber).

\section{Results and discussion}

Figures 1 and 2 show the dependence of the filament density $\left(\mathrm{g} / \mathrm{cm}^{3}\right)$ and crystallinity degree on the heater temperature $\mathrm{T}\left({ }^{\circ} \mathrm{C}\right)$ and texturing speed $\mathrm{Vi}(\mathrm{m} / \mathrm{min})$, at constant ratio of the surface disc speed to linear yarn speed D/Y: a) 1.7, b) 1.9, c) 2.1 and d) 2.3. Experimental results show that the increasing texturing speed has a more significant influence on the values of the tested characteristics at the heater temperature of $210^{\circ} \mathrm{C}$ than at the temperatures of 200 and $220^{\circ} \mathrm{C}$. The yarn density is reduced by lowering and increasing the temperature compared to the temperature of $210^{\circ} \mathrm{C}$ which is selected as a standard for the yarn with the tested fineness. Density values were obtained indirectly via a crystallinity degree, and therefore they show similar variations by changing texturing parameters.

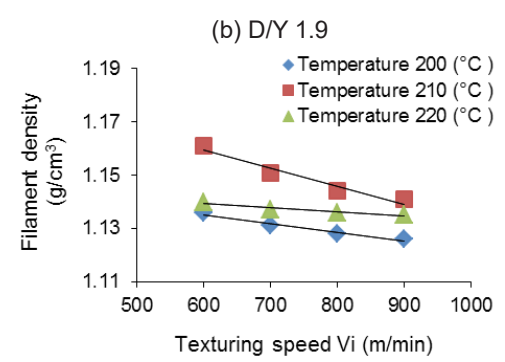

(d) $D / Y 2.3$

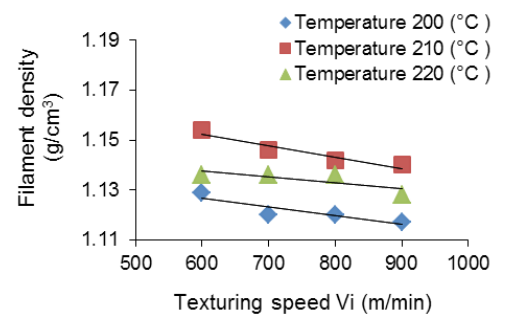

Figure 1. The dependence of filament density on the heater temperature $\mathrm{T}\left({ }^{\circ} \mathrm{C}\right)$ and the texturing speed $\mathrm{Vi}(\mathrm{m} / \mathrm{min})$, at constant ratio of the surface disc speed to the linear yarn speed D/Y: a) 1.7 , b) 1.9 , c) 2.1 , and d) 2.3 . 
(a) $\mathrm{D} / \mathrm{Y} 1.7$

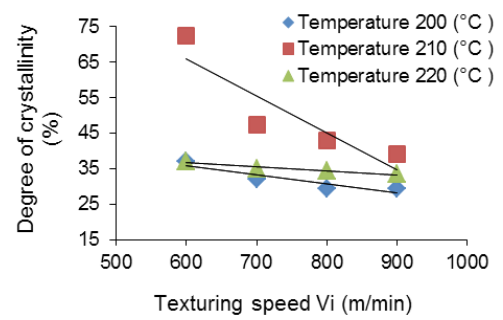

(c) $\mathrm{D} / \mathrm{Y} 2.1$

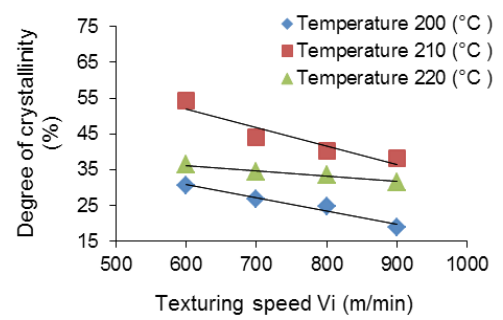

(b) $D / Y 1.9$

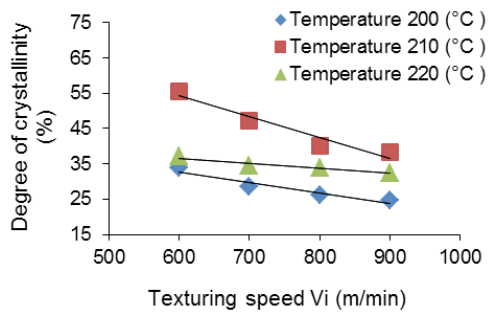

(d) $\mathrm{D} / \mathrm{Y} 2.3$

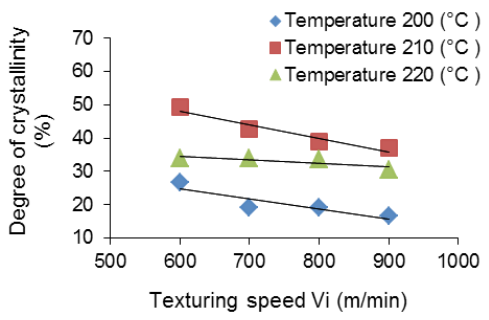

Figure 2. The dependence of a crystallinity degree (\%) on the heater temperature $\mathrm{T}\left({ }^{\circ} \mathrm{C}\right)$ and the texturing speed $\mathrm{Vi}(\mathrm{m} / \mathrm{min})$, at constant ratio of the surface disc speed to the linear yarn speed D/Y: a) 1.7, b) 1.9, c) 2.1, and d) 2.3 .

(a) $D / Y 1.7$

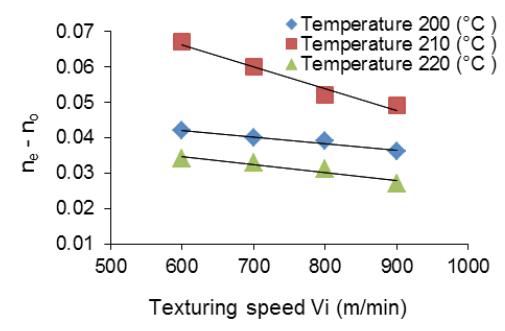

c) $D / Y 2.1$

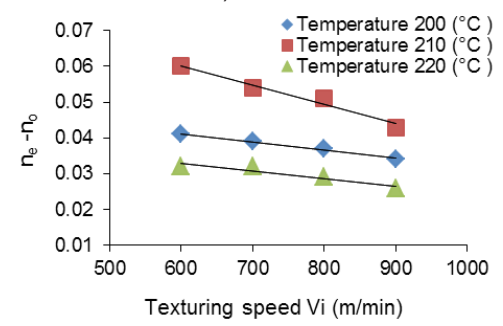

(b) $\mathrm{D} / \mathrm{Y} 1.9$

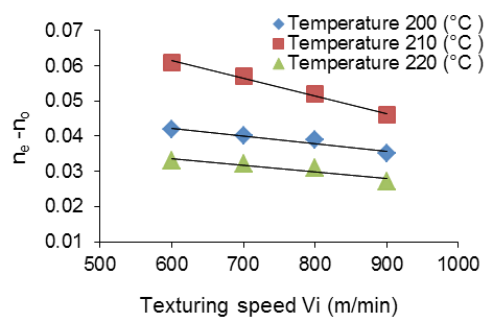

(d) $\mathrm{D} / \mathrm{Y} 2.3$

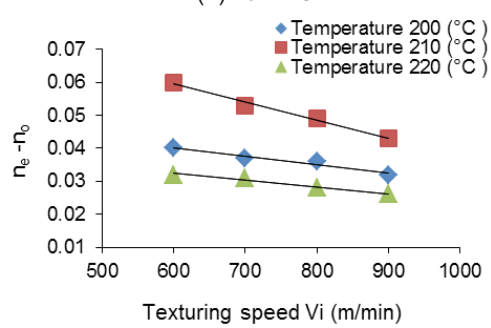

Figure 3. The dependence of double refraction, ne-no, on the heater temperature, $\mathrm{T}\left({ }^{\circ} \mathrm{C}\right)$, and texturing speed, $\mathrm{Vi}(\mathrm{m} / \mathrm{min})$, at constant ratio of the surface disc speed to the linear yarn speed D/Y: a) 1.7 , b) 1.9 , c) 2.1, and d) 2.3.

The degree of crystallinity of the textured yarn decreases with increasing the torque, which is determined by $\mathrm{D} / \mathrm{Y}$ ratio. The increase of the texturing speed corresponds to the reduced contact time of the yarn in the heater and cooling time of the yarn [13]. As the contact time of the yarn increases, the heat transfer from the heater into the filaments also increases and so does the time for crystallization.

The analysis of the obtained results shows that the increase of $\mathrm{D} / \mathrm{Y}$ ratio from 1.9 to 2.3 , for the heater temperature of 200,210 and $220{ }^{\circ} \mathrm{C}$ has an insignificant impact on reducing the degree of crystallinity. On the other hand, the reduction of $D / Y$ ratio to 1.7 leads to a significant increase in the degree of crystallinity, at lower speeds and the texturing temperature of $210^{\circ} \mathrm{C}$. Also, the degree of crystallinity decreases with increasing the speed $\mathrm{V}_{i}$, which is expected. At heaters temperature $\mathrm{T}$ $200-210^{\circ} \mathrm{C}$, the increase of the degree of crystallinity occurs, which can be explained by the increased mobility of molecule segments and the improved ability for crystallization. With the further increase in the heater temperature to $220^{\circ} \mathrm{C}$, the test results show that the degree of crystallinity decreases as a result of structural disorientation, the increased mobility of macromolecular segments and the increased content of low molecular weight fractions [14]. 
In Figure 3, the dependences of the degree of orientation of the individual filaments on the heater temperature $\mathrm{T}\left({ }^{\circ} \mathrm{C}\right)$ and texturing speed $\mathrm{Vi}_{\mathrm{i}}(\mathrm{m} / \mathrm{min})$ at a constant ratio of the surface disc speed and linear speed of the yarn D/Y: a) 1.7 , b) 1.9 , c) 2.1 , and d) 2.3 are shown. The orientation of individual filaments is expressed by the double refraction (ne-no), where higher values indicate better orientation.

According to literature data, the degree of orientation is influenced by two factors, namely the torsion tension that promotes disorientation of molecular chains and the tensile stress which further orients parts of molecular chains in the crystalline and amorphous regions. The effects of these factors gain in importance with the increase of the texturing temperature and better mobility of molecules [15-17].

The test results show that double refraction values increase with the increased heater temperature up to $210^{\circ} \mathrm{C}$, but at $220^{\circ} \mathrm{C}$ they decline. At $200^{\circ} \mathrm{C}$ lower double refraction values were obtained (for $D / Y$ 1.7: 0.042 0.036, D/Y 1.9: 0.042-0.035, D/Y 2.1: 0.041-0.034, D/Y 2.3: $0.040-0.032$ ), which can be explained by reduced mobility of macromolecular segments at lower heater temperature.
The temperature rise to $220^{\circ} \mathrm{C}$ leads to the reduced orientation (for $D / Y$ 1.7: $0.034-0.027, D / Y$ 1.9: 0.033 0.027, D/Y 2.1: 0.032-0.026, D/Y 2.3: 0.032-0.026) due to the increased mobility of macromolecules and not enough time for the structure relaxation.

It was observed that the increase of $\mathrm{D} / \mathrm{Y}$ ratio at heater temperatures 200,210 and $220^{\circ} \mathrm{C}$, only has a slight impact on reducing double refraction. Moreover, the double refraction is reduced with increasing the speed $\mathrm{Vi}$, as expected. The higher values of double refraction were obtained at T $210^{\circ} \mathrm{C}$ for the speeds Vi 600 and $700 \mathrm{~m} /$ min and the ratios $D / Y 1.7,1.9,2.1$ and 2.3. This phenomenon can be explained by the impact of the heater temperature on the fiber molecular structure and texturing speed as it was explained in the text on a crystallinity degree.

The correlation factor results for the filament density $\left(\mathrm{g} / \mathrm{cm}^{3}\right)$, crystallinity degree (\%) and double refraction ne-no, as dependent variables, and the texturing speed $\mathrm{Vi}(\mathrm{m} / \mathrm{min})$ as an independent variable, at three texturing temperatures of 200,210 and $220^{\circ} \mathrm{C}$ and $\mathrm{D} / \mathrm{Y}$ ratios of 1.7, 1.8, 2.1 and 2.3 are given in Tables 1, 2 and 3. For these relationships, straight lines equations are given.

Table 1. Straight line equation and correlation factor of a dependent variable for filament density $(\mathrm{g} / \mathrm{m} 3)$ and an independent variable of the texturing speed $\mathrm{Vi}(\mathrm{m} / \mathrm{min})$ at various heater temperatures $\mathrm{T}\left({ }^{\circ} \mathrm{C}\right)$ and $\mathrm{D} / \mathrm{Y}$ ratios.

\begin{tabular}{|c|c|c|c|}
\hline \multicolumn{2}{|c|}{$\begin{array}{l}\text { Texturing parameters: } \\
\mathrm{D} / \mathrm{Y} \text { ratios and heater temperatures }\end{array}$} & \multirow{2}{*}{$\begin{array}{c}\text { Linear equation } \\
y=-3 \cdot 10^{-5} x+1.156\end{array}$} & \multirow{2}{*}{$\begin{array}{c}\text { Correlation factor } \\
\mathrm{R}^{2}=0.833\end{array}$} \\
\hline & T $200\left({ }^{\circ} \mathrm{C}\right)$ & & \\
\hline \multirow[t]{3}{*}{$\mathrm{D} / \mathrm{Y} 1.7$ ratio } & T $210\left({ }^{\circ} \mathrm{C}\right)$ & $y=-x+1.241$ & $\mathrm{R}^{2}=0.800$ \\
\hline & T $220\left({ }^{\circ} \mathrm{C}\right)$ & $y=-1 \cdot 10^{-5} x+1.147$ & $\mathrm{R}^{2}=0.965$ \\
\hline & T $200\left({ }^{\circ} \mathrm{C}\right)$ & $y=-3 \cdot 10^{-5} x+1.155$ & $\mathrm{R}^{2}=0.959$ \\
\hline \multirow[t]{3}{*}{$\mathrm{D} / \mathrm{Y} 1.9$ ratio } & T $210\left({ }^{\circ} \mathrm{C}\right)$ & $y=-7 \cdot 10^{-5} x+1.199$ & $\mathrm{R}^{2}=0.948$ \\
\hline & T $220\left({ }^{\circ} \mathrm{C}\right)$ & $y=-2 \cdot 10^{-5} x+1.149$ & $\mathrm{R}^{2}=0.914$ \\
\hline & T $200\left({ }^{\circ} \mathrm{C}\right)$ & $y=-4 \cdot 10^{-5} x+1.158$ & $\mathrm{R}^{2}=0.980$ \\
\hline \multirow[t]{3}{*}{$\mathrm{D} / \mathrm{Y} 2.1$ ratio } & T $210\left({ }^{\circ} \mathrm{C}\right)$ & $y=-6 \cdot 10^{-5} x+1.191$ & $\mathrm{R}^{2}=0.904$ \\
\hline & T $220\left({ }^{\circ} \mathrm{C}\right)$ & $y=-3 \cdot 10^{-5} x+1.154$ & $\mathrm{R}^{2}=0.899$ \\
\hline & T $200\left({ }^{\circ} \mathrm{C}\right)$ & $y=-4 \cdot 10^{-5} x+1.148$ & $\mathrm{R}^{2}=0.800$ \\
\hline \multirow[t]{2}{*}{$\mathrm{D} / \mathrm{Y} 2.3$ ratio } & T $210\left({ }^{\circ} \mathrm{C}\right)$ & $y=-5 \cdot 10^{-5} x+1.180$ & $\mathrm{R}^{2}=0.920$ \\
\hline & T $220\left({ }^{\circ} \mathrm{C}\right)$ & $y=-2 \cdot 10^{-5} x+1.152$ & $\mathrm{R}^{2}=0.600$ \\
\hline
\end{tabular}

Table 2. Straight line equation and correlation factor of a dependent variable for a degree of crystallinity (\%) and an independent variable of the texturing speed $\mathrm{Vi}(\mathrm{m} / \mathrm{min})$, at various heater temperatures $\mathrm{T}\left({ }^{\circ} \mathrm{C}\right)$ and $\mathrm{D} / \mathrm{Y}$ ratios.

\begin{tabular}{|c|c|c|c|}
\hline \multicolumn{2}{|c|}{$\begin{array}{l}\text { Texturing parameters: } \\
D / Y \text { ratios and heater temperatures }\end{array}$} & Linear equation & Correlation factor \\
\hline \multirow{3}{*}{$\mathrm{D} / \mathrm{Y} 1.7$ ratio } & T $200\left({ }^{\circ} \mathrm{C}\right)$ & $y=-0.025 x+51.14$ & $\mathrm{R}^{2}=0.833$ \\
\hline & T $210\left({ }^{\circ} \mathrm{C}\right)$ & $y=-0.104 x+128.9$ & $\mathrm{R}^{2}=0.805$ \\
\hline & T $220\left({ }^{\circ} \mathrm{C}\right)$ & $y=-0.011 x+43.42$ & $\mathrm{R}^{2}=0.945$ \\
\hline \multirow{3}{*}{$\mathrm{D} / \mathrm{Y} 1.9$ ratio } & T $200\left({ }^{\circ} \mathrm{C}\right)$ & $y=-0.029 x+50.50$ & $\mathrm{R}^{2}=0.920$ \\
\hline & T $210\left({ }^{\circ} \mathrm{C}\right)$ & $y=-0.059 x+89.71$ & $\mathrm{R}^{2}=0.940$ \\
\hline & T $220\left({ }^{\circ} \mathrm{C}\right)$ & $y=-0.014 x+45.03$ & $\mathrm{R}^{2}=0.930$ \\
\hline \multirow{3}{*}{$\mathrm{D} / \mathrm{Y} 2.1$ ratio } & T $200\left({ }^{\circ} \mathrm{C}\right)$ & $y=-0.036 x+52.74$ & $\mathrm{R}^{2}=0.962$ \\
\hline & T $210\left({ }^{\circ} \mathrm{C}\right)$ & $y=-0.052 x+83.28$ & $\mathrm{R}^{2}=0.880$ \\
\hline & T $220\left({ }^{\circ} \mathrm{C}\right)$ & $y=-0.015 x+45.51$ & $\mathrm{R}^{2}=0.984$ \\
\hline \multirow{3}{*}{$\mathrm{D} / \mathrm{Y} 2.3$ ratio } & T $200\left({ }^{\circ} \mathrm{C}\right)$ & $y=-0.030 x+43.42$ & $\mathrm{R}^{2}=0.800$ \\
\hline & T $210\left({ }^{\circ} \mathrm{C}\right)$ & $y=-0.040 x+72.35$ & $\mathrm{R}^{2}=0.941$ \\
\hline & T $220\left({ }^{\circ} \mathrm{C}\right)$ & $y=-0.01 x+40.37$ & $\mathrm{R}^{2}=0.679$ \\
\hline
\end{tabular}


Table 3. Straight line equation and a correlation factor of a dependent variable for double refraction ne-no and an independent variable of the texturing speed $\mathrm{Vi}(\mathrm{m} / \mathrm{min})$ at various heater temperatures $\mathrm{T}\left({ }^{\circ} \mathrm{C}\right)$ and $\mathrm{D} / \mathrm{Y}$ ratios.

\begin{tabular}{cccc}
\hline \multicolumn{2}{c}{ Texturing parameters: } & Linear equation & Correlation factor \\
\hline D/Y ratios and heater temperatures & T $200\left({ }^{\circ} \mathrm{C}\right)$ & $\mathrm{y}=-2 \cdot 10^{-5} \mathrm{x}+0.053$ & $\mathrm{R}^{2}=0.962$ \\
$\mathrm{D} / \mathrm{Y} 1.7$ ratio & $\mathrm{T} 210\left({ }^{\circ} \mathrm{C}\right)$ & $\mathrm{y}=-6 \cdot 10^{-5} \mathrm{x}+0.103$ & $\mathrm{R}^{2}=0.970$ \\
& $\mathrm{~T} 220\left({ }^{\circ} \mathrm{C}\right)$ & $\mathrm{y}=-2 \cdot 10^{-5} \mathrm{x}+0.048$ & $\mathrm{R}^{2}=0.920$ \\
$\mathrm{D} / \mathrm{Y} 1.9$ ratio & $\mathrm{T} 200\left({ }^{\circ} \mathrm{C}\right)$ & $\mathrm{y}=-2 \cdot 10^{-5} \mathrm{x}+0.055$ & $\mathrm{R}^{2}=0.930$ \\
& $\mathrm{~T} 210\left({ }^{\circ} \mathrm{C}\right)$ & $\mathrm{y}=-5 \cdot 10^{-5} \mathrm{x}+0.091$ & $\mathrm{R}^{2}=0.992$ \\
& $\mathrm{~T} 220\left({ }^{\circ} \mathrm{C}\right)$ & $\mathrm{y}=-2 \cdot 10^{-5} \mathrm{x}+0.045$ & $\mathrm{R}^{2}=0.869$ \\
$\mathrm{D} / \mathrm{Y} 2.1$ ratio & $\mathrm{T} 200\left({ }^{\circ} \mathrm{C}\right)$ & $\mathrm{y}=-2 \cdot 10^{-5} \mathrm{x}+0.055$ & $\mathrm{R}^{2}=0.988$ \\
& $\mathrm{~T} 210\left({ }^{\circ} \mathrm{C}\right)$ & $\mathrm{y}=-5 \cdot 10^{-5} \mathrm{x}+0.092$ & $\mathrm{R}^{2}=0.972$ \\
& $\mathrm{~T} 220\left({ }^{\circ} \mathrm{C}\right)$ & $\mathrm{y}=-2 \cdot 10^{-5} \mathrm{x}+0.045$ & $\mathrm{R}^{2}=0.890$ \\
$\mathrm{D} / \mathrm{Y} 2.3$ ratio & $\mathrm{T} 200\left({ }^{\circ} \mathrm{C}\right)$ & $\mathrm{y}=-2 \cdot 10^{-5} \mathrm{x}+0.055$ & $\mathrm{R}^{2}=0.954$ \\
& $\mathrm{~T} 210\left({ }^{\circ} \mathrm{C}\right)$ & $\mathrm{y}=-5 \cdot 10^{-5} \mathrm{x}+0.092$ & $\mathrm{R}^{2}=0.990$ \\
& $\mathrm{~T} 220\left({ }^{\circ} \mathrm{C}\right)$ & $\mathrm{y}=-2 \cdot 10^{-5} \mathrm{x}+0.045$ & $\mathrm{R}^{2}=0.969$ \\
\hline
\end{tabular}

On the basis of the correlation factor, the best correlation of the tested parameters $\mathrm{V}_{i}(\mathrm{~m} / \mathrm{min})$ and $\mathrm{T}^{\circ} \mathrm{C}$ with the filament density was found at:

- $D / Y 1.7$ ratio - heater temperature $220^{\circ} \mathrm{C}(R 2=0.965)$

- $D / Y 1.9$ ratio - heater temperature $200{ }^{\circ} \mathrm{C}(R 2=0.959)$

- $\mathrm{D} / \mathrm{Y} 2.1$ ratio - heater temperature $200^{\circ} \mathrm{C}(\mathrm{R} 2=0.980)$

- $D / Y 2.3$ ratio - heater temperature $210^{\circ} \mathrm{C}(R 2=0.920)$

On the basis of the correlation factor, the best correlation of the tested parameters $\mathrm{Vi}(\mathrm{m} / \mathrm{min})$ and $\mathrm{T}^{\circ} \mathrm{C}$ with the crystallinity degree was found at:

- $\mathrm{D} / \mathrm{Y} 1.7$ ratio - heater temperature $220^{\circ} \mathrm{C}(\mathrm{R} 2=0.945)$

- $D / Y 1.9$ ratio - heater temperature $210^{\circ} \mathrm{C}(R 2=0.940)$

- D/Y 2.1 ratio - heater temperature $220^{\circ} \mathrm{C}(\mathrm{R} 2=0.984)$

- $D / Y 2.3$ ratio - heater temperature $210^{\circ} \mathrm{C}(\mathrm{R} 2=0.941)$

On the basis of the correlation factor, the best correlation of the tested parameters $\mathrm{Vi}(\mathrm{m} / \mathrm{min})$ and $\mathrm{T}^{\circ} \mathrm{C}$ with double refraction ne-no was found at:

- $D / Y 1.7$ ratio - heater temperature $210^{\circ} \mathrm{C}(R 2=0.970)$

- $D / Y 1.9$ ratio - heater temperature $210^{\circ} \mathrm{C}(\mathrm{R} 2=0.992)$

- D/Y 2.1 ratio - heater temperature $200^{\circ} \mathrm{C}(\mathrm{R} 2=0.988)$

- $D / Y 2.3$ ratio - heater temperature $210^{\circ} \mathrm{C}(\mathrm{R} 2=0.990)$

It is observed that the optimum value of $D / Y$ ratio for

(a) $D / Y 1.7$

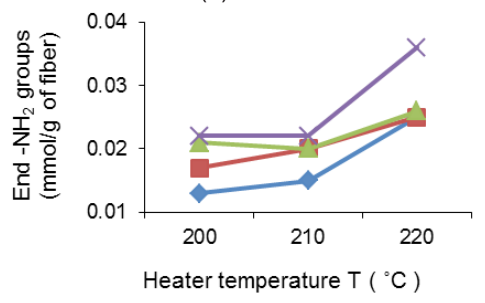

(c) $D / Y 2.1$

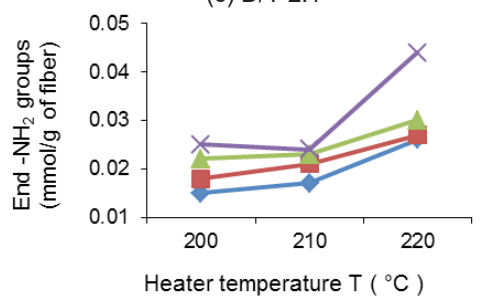

the tested yarn property is as follows: for filament density 2.1 , for crystallinity degree 2.1 while for the double refraction the best value of $D / Y$ ratio is 1.9 . It can be concluded that the limit value of $D / Y$ ratio is 2.1 for the tested yarn fineness.

Figure 4 shows the dependence of the content of end $-\mathrm{NH}_{2}$ groups on the heater temperature $\mathrm{T}\left({ }^{\circ} \mathrm{C}\right)$ and the texturing speed $\mathrm{Vi}(\mathrm{m} / \mathrm{min})$ at constant ratio of the surface disc speed to the linear yarn speed $D / Y$ of a) $1.7, b$ ) 1.9, c) 2.1 and d) 2.3 .

Test results show that the heater temperature has a great impact on the content of end $-\mathrm{NH}_{2}$ groups. It was observed that the content of $-\mathrm{NH}_{2}$ groups increases slightly with increasing the texturing speed at heater temperatures 200 and $210^{\circ} \mathrm{C}$. But at the temperature of $220^{\circ} \mathrm{C}$, much greater variations with the speed increase are observed. This can be explained as a degradation of molecular chains due to the heater temperature. By changing the $\mathrm{D} / \mathrm{Y}$ ratio from 1.7 to 1.9 , at the temperature of $220^{\circ} \mathrm{C}$, the variations are marginal. These changes have a slight increase with the change of $D / Y$ ratio from to 2.1 to 2.3 at $220{ }^{\circ} \mathrm{C}$. When $\mathrm{D} / \mathrm{Y}$ ratio changes

(b) $D / Y 1.9$

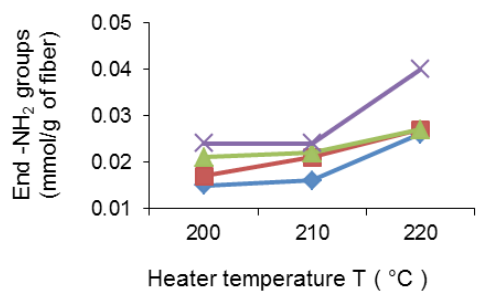

(d) $D / Y 2.3$

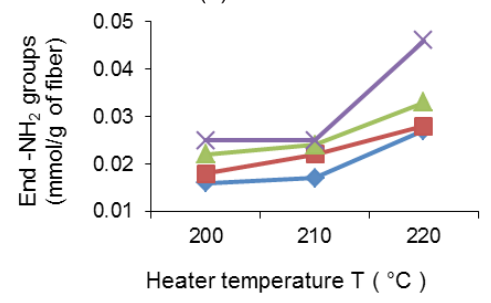

Figure 4. The dependence of $-\mathrm{NH}_{2}$ end group content (mmol/g fiber) on the heater temperature $\mathrm{T}\left({ }^{\circ} \mathrm{C}\right.$ ) and texturing speed $\mathrm{Vi}$ $(\mathrm{m} / \mathrm{min})$ at constant ratio of the surface disc speed to the linear yarn speed $\mathrm{D} / \mathrm{Y}$ of: a) $1.7, \mathrm{~b}) 1.9, \mathrm{c}) 2.1$ and d) 2.3 . 
(a) $\mathrm{D} / \mathrm{Y} 1.7$

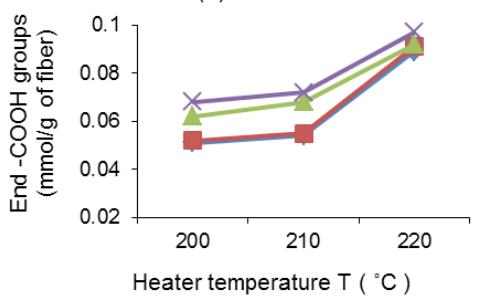

(c) $D / Y 2.1$

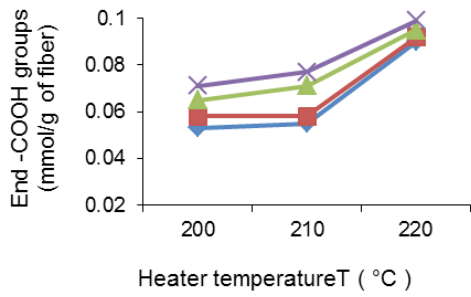

(b) $\mathrm{D} / \mathrm{Y} 1.9$

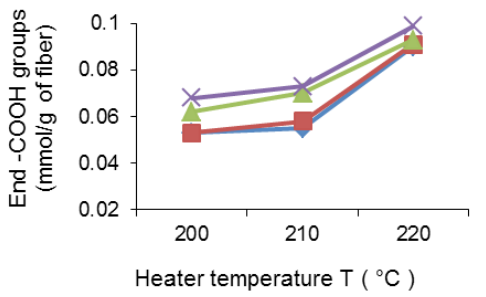

(d) $D / Y 2.3$

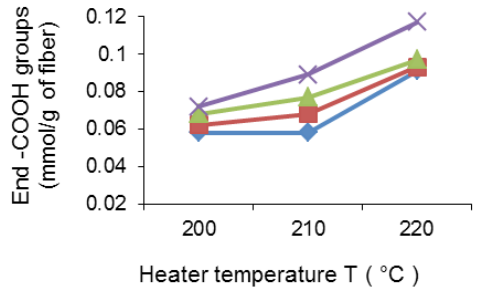

Figure 5. The dependence of $-\mathrm{COOH}$ end group content (mol/g fiber) on the heater temperature $\mathrm{T}\left({ }^{\circ} \mathrm{C}\right)$ and the texturing speed $\mathrm{Vi}(\mathrm{m} / \mathrm{min})$ at constant ratio of the surface disc speed to the linear yarn speed D/Y of: a) 1.7, b) 1.9, c) 2.1 and d) 2.3.

from 1.7 to 2.3 at lower temperatures of 200 and $210^{\circ} \mathrm{C}$, greater changes are observed at lower $\mathrm{D} / \mathrm{Y}$ ratio of 1.7 at $\mathrm{T} 210^{\circ} \mathrm{C}$. D/Y ratio is one of the critical parameters of the texturing process, and its selection is very important for optimal adjustment of the process condition.

Figure 5 shows the dependence of the content of end $-\mathrm{COOH}$ groups on the heater temperature $\mathrm{T}\left({ }^{\circ} \mathrm{C}\right)$ and the texturing speed $\mathrm{Vi}(\mathrm{m}(\mathrm{min})$ at constant ratio of the surface disc speed to the linear yarn speed $D / Y$ of a) $1.7, b$ ) 1.9 , c) 2.1 and d) 2.3 .

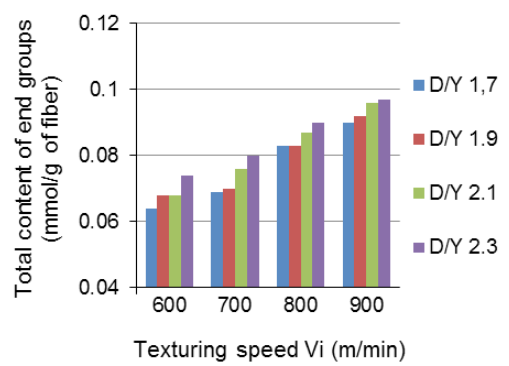

Figure 6. The dependence of the total content of end groups ( $\mathrm{mmol} / \mathrm{g}$ fiber) on $\mathrm{D} / \mathrm{Y}$ ratio and the texturing speed $\mathrm{Vi}(\mathrm{m} / \mathrm{min})$, at constant heater temperature of $200{ }^{\circ} \mathrm{C}$

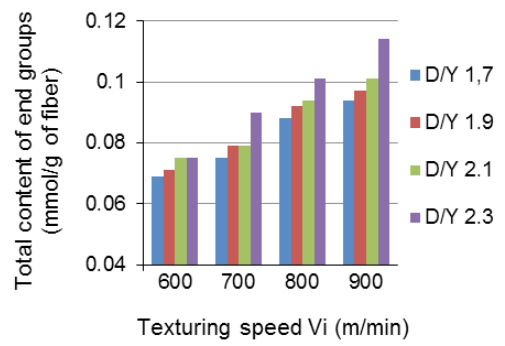

Figure 7. The dependence of the total content of end groups (mmol/g fiber) on $\mathrm{D} / \mathrm{Y}$ ratio and the texturing speed $\mathrm{Vi}(\mathrm{m} / \mathrm{min})$, at constant heater temperature of $210^{\circ} \mathrm{C}$

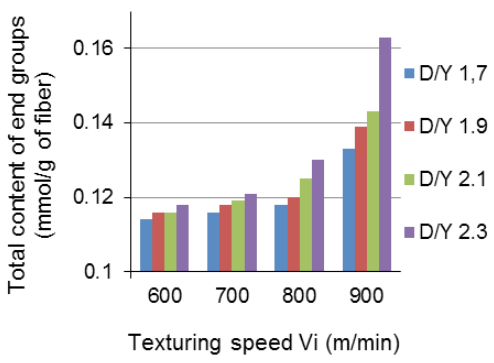

Figure 8. The dependence of the total content of end groups ( $\mathrm{mmol} / \mathrm{g}$ fiber) on $\mathrm{D} / \mathrm{Y}$ ratio and the texturing speed $\mathrm{Vi}(\mathrm{m} / \mathrm{min})$, at constant heater temperature of $220^{\circ} \mathrm{C}$

Analyzing the results obtained, it can be noticed that the heater temperature has a great impact on the content of end $-\mathrm{COOH}$ groups as in the case of the content of end $-\mathrm{NH}_{2}$ groups. A higher increase is observed at higher heater temperatures of $220^{\circ} \mathrm{C}$. At $\mathrm{D} / \mathrm{Y}$ ratio of 1.7 , 1.9 and 2.1 , the content of end $-\mathrm{COOH}$ groups slightly increases with the increase of the texturing speed at 200 and $210^{\circ} \mathrm{C}$. However, at the temperature of $220^{\circ} \mathrm{C}$, the changes are minimal with increasing the speed. At D/Y ratio of 2.3 the content of end $-\mathrm{COOH}$ groups slightly increases with the texturing speed, at heater temperatures of 210 and $220^{\circ} \mathrm{C}$. The changes at $200{ }^{\circ} \mathrm{C}$ are minimal.

Figure 6 shows the dependence of the total content of end groups on $\mathrm{D} / \mathrm{Y}$ ratio and texturing speed $\mathrm{Vi}(\mathrm{m} /$ $\min )$, at the constant heater temperature of $\mathrm{T} 200^{\circ} \mathrm{C}$.

Figure 7 shows the dependence of the total content of end groups on $\mathrm{D} / \mathrm{Y}$ ratio and the texturing speed $\mathrm{V}_{\mathrm{i}}$ $(\mathrm{m} / \mathrm{min})$, at the constant heater temperature of $\mathrm{T} 210^{\circ} \mathrm{C}$.

Figure 8 shows the dependence of the total content of end groups on $\mathrm{D} / \mathrm{Y}$ ratio and the texturing speed $\mathrm{Vi}_{\mathrm{i}}$ $(\mathrm{m} / \mathrm{min})$, at the constant heater temperature of $\mathrm{T} 220^{\circ} \mathrm{C}$.

The test results (Figures 6, 7 and 8) show that the ratio $D / Y$ has a marginal impact on the total content of 
end groups at the lower temperature $\mathrm{T} 200^{\circ} \mathrm{C}$ while this impact slightly increases with the increase of the heater temperature to 210 and $220^{\circ} \mathrm{C}$. A slight increase of the total content of end groups is observed with changing the speed $V_{i}$, except at $D / Y 2.3$ and at higher temperatures of 210 and $220{ }^{\circ} \mathrm{C}$, where the changes are somewhat bigger.

\section{Conslusion}

The analysis of the influence of the heater temperature, the texturing speed and $\mathrm{D} / \mathrm{Y}$ ratio on the tested characteristics of the yarn indicates the following conclusions:

- Variations of texturing parameters ( $T$, Vi and $D / Y)$ impact the structural yarn changes to varying degrees.

- Variations of the heater temperature have a higher impact on the crystallinity degree, density and orientation of individual filaments than the texturing speed and $D / Y$ ratio, as it is expected.

- A decrease of the heater temperature, relative to the temperature of $210^{\circ} \mathrm{C}$, also leads to the decrease of the crystallinity degree and orientation degree. This can be explained by a reduced mobility of molecule segments and a reduced ability to crystalize.

- The increase of the heater temperature, relative to the temperature of $210{ }^{\circ} \mathrm{C}$, also leads to the decrease of the crystallinity degree and orientation degree. This can be explained by the increased mobility of molecule segments and lack of time for relaxation of outstanding tensions in the yarn as a result of texturing, as well as the increase of the content of low molecular fractions.

- The heater temperature has a more significant influence on the content of end groups than the texturing speed and $D / Y$ ratio. Under the influence of temperatures above $220^{\circ} \mathrm{C}$, for the tested yarn fineness, the variations in the total content of end groups can be explained as the shortening of macromolecular chains under the influence of a high heater temperature. In the further yarn finishing process, especially dyeing, the increased content of end groups is very important. It affects the quality of the yarn dyeing and, above all, the leveling of dyeing.

Higher values of $D / Y$ ratio mean a greater speed of the disc in relation to the speed of the yarn, so more torque is transferred to the yarn. This leads to a higher twist of the yarn, but slippage can occur between the yarn and the disc. This increases the instability yarn tension causing higher variations in the characteristics of the textured yarn [18-21]. Consequently, the test results were obtained, where the optimum values of the $D / Y$ ratio were 1.9 and 2.1 , and the limit value of $D / Y$ was 2.1 for the tested yarn fineness.

Based on the analysis of the test results, one can draw up recommendations for the optimum parameters of texturing to obtain the best structural characteristics of the yarn. For texturing of polyamide, the multifilament fineness $22 \mathrm{f} 07 \times 1 \mathrm{dtex}$, the optimum temperature of the heater is up to $210^{\circ} \mathrm{C}$; the $\mathrm{D} / \mathrm{Y}$ ratio 1.9 to 2.1 , whereby the selection of texturing speeds values of $700-800 \mathrm{~m} /$ min was taken into account and the tension in the texturing (stretching) zone was 1.305 and 0.954 in the winding zone.

\section{References}

[1] D. R. Salem, Structure Formation in Polymeric Fibers, Hanser Gardner, 2001.

[2] K. Katayama, M.Tsuji, Fundamentals of Spinning, in Advanced Fiber Spinning Technology, ed. T.Nakajima, Woodhead publishing Ltd., Cambridge, 1994.

[3] A. Ziabicki, Fundamentals of fibre formation, John Wiley \& Sons, London, 1976.

[4] S. M. Kveder, T. Rijavec, Textile Research Journel, 64, (1994), p.495.

[5] H.Tawanai, M.J.Denton, J.G. Tomka, Journal of the Textile Institute, 88, (1997), p.107.

[6] D. S. Barnes, W.J.Morris, Journal of the Textile Institute, 71, (1980), p. 299.

[7] J W S Hearle, L Hollick and D K Wilson, Yarn texturing technology, Woodhead Publishing Limited, Oxford Cambridge New Delhi 2001.

[8] S. Ghosh, J. Wolhar, Textile Research Journal, 51, (1981), p. 373.

[9] R. S. Jovanović: Struktura i Svojstva vlakana, Tehnološko - Metalurški fakultet, Beograd (1981)

[10] J. O. Werwicker, Lenzinger Berichte, 47, (1979), p. 221.

[11] A. Jain, K. Vijayan, Journal of Materials Science, 37, (2002), 2623.

[12] M. L. Tate, Y. K. Kamath, S. P. Wesson, S. B. Ruetsch, Journal of Colloid and Interface Science, 177, (1996), p. 579.

[13] H. C. Karakaş and H. Dayioğlu, Influence of major falsetwist texturing parameters on the structural properties of polyamide 6.6 yarn. FIBRES \& TEXTILES in Eastern Europe, 12, 2, 46, (2004) 23-28.

[14] S. M. Kveder and T. Rijavec, Dynamic mechanical properties, superstructure and texturability of PA 6.6 partially oriented yarns. Textile Research Journal, 64, 9, (1994) 495-500.

[15] B. Wulfhorst and K. Meier, Investigations on a short high temperature heater. Chemiefasern - Textilindustrie, 43, 95, (1993) p. 40.

[16] S. Ghosh, St. Lucas, Texturing - Heat transfer in highspeed draw-texturing. Chemiefasern, Textil-Industrie, 50, 5, (2000) p. 488.

[17] O. Kaltenecker, Texturing - Spin finishes drive texturing machinery. Chemiefasern, Textil-Industrie, 54, 5, (2004) p. 331.

[18] H. C. Karakaş and H. Dayioğlu, Use of high-temperature heaters in false-twist texturing machines. Textile Institute 81st World Conference, Melbourne, Australia, 1-4 April , 2001.

[19] B. Schmenk, B. Wulfhorst, T. Gries and N. Schedukat, New developments for online quality control in high-speed false-twist texturing. Chemical Fibers International, 52, (2002) 352-353.

[20] B. Schmenk, B. Wulfhorst, T. Gries and N. Schedukat, Ensuring process stability and yarn quality in high-speed false-twist texturing. Chemical Fibers Inter-national, 52, (2002) 348-351.

[21] $\mathrm{H}$. Weinsdörfer, Measures for increasing output in texturing. Chemical Fibers International, 51, (2002) 370-372. 
Izvod

\section{UTICAJ VARIJACIJE RAZLIČITIH PROCESNIH PARAMETARA TEKSTURIRANJA NA STRUKTURNE KARAKTERISTIKE POLIAMIDNIH TEKSTURIRANIH PREĐA KOD “FALS-TWIST” UPREDANJA}

Marija Savić1 ${ }^{1}$ Dušan Trajković 1 , Petar Stojanović ${ }^{2}$, Jovan Stepanović ${ }^{1}$

1Tehnološki fakultet, Leskovac, Srbija

2Dunav a.d. Grocka, Srbija

Varijacije procesnih parametara teksturiranja u granicama mogućnosti industrijske mašine za teksturiranje, dovode do bitnih promena strukturnih karakteristika pređe. Za dobijanje teksturirane PA6.6 pređe željenih karakteristika i za određenu namenu, neophodno je podešavanje optimalnih procesnih parametara. Iz tog razloga, pored modifikovanja kvaliteta teksturiranih poliamidnih pređa, cilj rada predstavlja definisanje graničnih vrednosti procesa teksturiranja. U radu je ispitivan uticaj tehničko-tehnoloških parametara u procesu teksturiranja lažnim upredanjem na strukturne karakteristike poliamidnih pređa. Delimično orijentisani POY multifilament finoće 22f07x1 dtex teksturiran je u proizvodnim uslovima na mašini za frikciono teksturiranje ICBT model FT 15 E3. Korišćenjem niskotemperaturnih dugih grejača razmatran je uticaj varijacije temperature grejača, brzine teksturiranja i odnosa D/Y na svojstva teksturirane pređe (gustine filamenata, stepena kristalnosti, stepena orijentisanosti pojedinačnih filamenata, sadržaja krajnjih $-\mathrm{NH}_{2}$ grupa, sadržaja -COOH grupa i ukupnog sadržaja krajnjih grupa). Pri čemu su zadržane konstantne vrednosti zategnutosti u zoni teksturiranja (istezanje) 1.305 a u zoni namotavanja 0.954 . Proučavani parametri teksturiranja u različitoj meri utiču na promenu navedenih karakteristika. Za temperature grejača 200,210 i $220{ }^{\circ} \mathrm{C}$ i odnos $\mathrm{D} / \mathrm{Y} 1.7,1.9,2.1 \mathrm{i}$ 2.3, linearne negativne korelacije ustanovljene su između brzine teksturiranja - gustine filamenata, brzine teksturiranja - stepena kristalnosti i brzine teksturiranja - stepena orijentisanosti pojedinačnih filamenata. Određivan je faktor korelacije između procesnih parametara teksturiranja i analiziranih svojstava pređa. Na osnovu analize dobijenih rezultata može se izvesti zaključak, da se kod uspostavljenih korelacija između brzine teksturiranja i ispitivanih svojstava pređe, faktor korelacije uglavnom povećava sa porastom odnosa $D / Y$ do $1.9 \mathrm{i}$ 2.1 , na temperaturi grejača do $210^{\circ} \mathrm{C}$. Međutim na temperaturi od $220^{\circ} \mathrm{C}$ i većim vrednostima odnosa D/Y, u većini slučajeva faktor korelacije opada. Prema tome u ovom istraživanju, optimalna temperatura grejača je $210^{\circ} \mathrm{C}$, odnos $\mathrm{D} / \mathrm{Y} 1.9-2.1$ uzevši u obzir odabir ostalih vrednosti parametara brzine teksturiranja i istezanja.
(ORIGINALNI NAUČNI RAD)

UDK 677.072.7:677.022

Ključne reči: lažno upredanje, parametri teksturiranja, teksturirane pređe, strukturne karakteristike 